\title{
O estado do ensino, uma pequena contribuição
}

\author{
A. M. BOTELHO DO REGO*
}

\footnotetext{
Q
} JANDO SE TRATA DE DISCUTIR O ESTADO do ensino no país entramos sempre num terreno escorregadio passivel de gerar mal-entendidos, mal-estar, acusaçōes cruzadas, brios feridos, etc. $\mathrm{Na}$ verdade, para encontrar soluções, curas para a doença (penso que neste momento poucos negarão a sua existência...) de que enferma o nosso ensino, é necessário diagnosticá-la, o que é uma verdade de La Palice ${ }^{1}$. E é aqui que a questão se complica. Quando se começa a escalpelizar o assunto há sempre alguns (ou muitos) que se sentem pessoalmente atacados e que reagem como primas-donnas ofendidas.

Ora este artigo(zinho) dificilmente suscitará reacções de ofensa por parte de alguém. Não por medo da autora mas por pura incompetência. Com efeito, quando tentei iniciar a tarefa de diagnóstico deparei-me com um problema do tipo ovo/galinha. Quem estará a funcionar mal: o Ensino Infantil que devia existir e praticamente não existe? O Ensino Primário ${ }^{2}$ que estabelece (estabelece mesmo?) metas pouco ambiciosas para um escalão etário que está em estado de esponja relativamente à aquisição de conhecimentos e ao desenvolvimento de aptidões? Ao Ensino Secundário ${ }^{2}$ que se recusa, por exemplo, a desenvolver a capacidade dedutiva e de abstracção dos alunos ${ }^{3}(!)$ ? Ao Ensino Superior que, entre muitas outras coisas, deveria preparar professores (para todos os graus de ensino) cientifica-, pedagogica- e eticamente habilitados para instruir mas sobretudo para educar? Por que ponta se deve pegar? Pelo Ensino Superior que fornece professores para todos os outros graus e se auto-abastece? Pois, mas a matéria prima que recebe vem dos outros graus de Ensino... Cá está o ovo e a galinha ou a pescadinha de rabo na boca. E para complicar a questão há também, e se calhar em pé de igualdade em termos de importância, os factores sócio-económicos que contribuem para a questão.

Pronto (ou será prontos?). Os chavões estão cá todos e nesta altura da análise é bem patente a incapacidade da autora para apontar SOLUçÕES para o que quer que seja (c.q.d.).

Porquê este pequeno artigo (desabafo), então?

Porque penso que, no estado em que as coisas estão todas as contribuições bem intencionadas (e essa é a única característica que eu posso garantir neste caso) são bem-vindas, mesmo estando o Inferno cheio de bem intencionados.

O que eu tenho para partilhar com os leitores é um conjunto de observações que tenho feito ao longo dos últimos anos de docência e que me têm deixado particularmente preocupada. È certo que se trata de observações sobre um número reduzido de alunos. Mas a maneira de saber se estas observaçōes têm algum significado estatístico, se correspondem a comportamentos médios e portanto exigem medidas imediatas e eficazes ou se, pelo contrário, foram observações fortuitas feitas por alguém que tem o azar de cair em situaçōes complicadas, ou que é pura e simplesmente pessimista, é precisamente publicando-as, publicitando-as e escutando o eco.
Passemos então às observações:

1. ${ }^{\circ}$ Exemplo: A um conjunto de 130 alunos do $1 .^{\circ}$ ano de uma licenciatura de Engenharia (não Química) a quem foi explicado nas aulas teóricas e nas aulas de problemas (no âmbito de uma disciplina de Química Geral) o que era uma liga metálica intersticial e uma liga metálica de substituição ${ }^{4}$ foi posto 0 seguinte problema:

O cobre metálico puro tem uma massa volúmica de $8,96 \mathrm{~g} / \mathrm{cm}^{3}$, à temperatura ambiente. Uma liga de cobre com um elemento desconhecido $X$ tem, nas mesmas condições uma massa volúmica de $8,85 \mathrm{~g} / \mathrm{cm}^{3}$. i) De que tipo de liga se trata? ii) Sabendo que a percentagem de elemento $X$ é de $2,2 \%$ e admitindo que a contribuição de defeitos é desprezável, identifique X. Justifique apresentando os cálculos.

Como resposta à alínea i) pretendia-se qualquer coisa como: "Uma vez que uma liga intersticial com pequena percentagem de outro elemento tem sempre de ter uma massa volúmica superior à do metal puro, esta liga tem de ser de substituiçăo e o elemento $\mathrm{X}$ tem de ser mais leve do que o cobre". Dos 130 alunos, 2 (dois; não é gralha...) responderam correctamente à pergunta. Repare-se que o aluno para responder a esta questão necessita apenas da definição de liga de substituiçăo e intersticial, do conceito de massa volúmica e de capacidade de raciocínio. Expliquei a duas pessoas que têm como nível máximo de instrução a antiga $4 .{ }^{\circ}$ classe o que eram os dois tipos de liga e o que é massa volúmica e essas pessoas não tiveram difi- 
culdade nenhuma em responder à pergunta sem necessidade de efectuar qualquer cálculo.

Já a resolução da alínea ii) exige alguma ferramenta especifica: 0 aluno tem de saber "ler" a estrutura cristalina de um dado metal na Tabela Periódica, tem depois de saber descrevê-la, tem de saber contabilizar os átomos do metal e do elemento substituinte numa célula cúbi$\mathrm{ca}$, tem de saber relacionar o volume dessa célula com as dimensões lineares do átomo, etc

Como nas aulas de problemas tinha sido resolvido, em todas as turmas, um exercício em que era pedida a massa volúmica de uma liga de substituição dada a sua composição, quase todos os alunos "pegaram" na questão e a trataram como um problema relativo a uma liga de substituição independentemente da resposta que tinham dado na alínea a). É verdade que, destes todos, apenas um encontrou de facto a resposta para o problema mas grande parte deles obteve mais de metade da cotação. Note-se que nesse conjunto de 127 alunos havia uma boa dezena de bons alunos (nota final na cadeira $\geq 14$ valores). Um dos dois alunos que respondeu correctamente à alínea a) teve uma nota global na prova que dava direito a oral (menor do que 9,5 e maior do que 8). Assim, quando revi a prova verifiquei que o aluno não "pegou" na alínea b). Quando Ihe perguntei porquê ele afirmou-me com toda a honestidade que não fazia a mínima ideia de como tratar o problema quantitativamente. Devo confessar que não tive paciência para ir rever as outras 126 provas para verificar o que tinha feito o outro aluno que respondeu correctamente à alínea a) mas não ficaria admirada se a sua resposta à alínea b) tivesse sido classificada com um rotundo zero.

2. ${ }^{\circ}$ Exemplo: Num exame da disciplina de Fenómenos de Transferência leccionada (por um colega meu e não por mim) no $3 .^{\circ}$ ano do curso de Engenharia Química, havia um problema clássico de permutadores de calor. Eram dadas as características do permutador e a temperatura de entrada da água $\left(25^{\circ} \mathrm{C}\right)$ e de saída do óleo $\left(>100^{\circ} \mathrm{C}\right)$. Um aluno conhecia completamente o modo de resolver o problema mas enganou-se em alguns cálculos (as "fórmulas" estavam todas certas) e obteve uma temperatura de saída da água de $-10^{\circ} \mathrm{C}$ (menos 10 graus Celsius). 0 meu colega classificou o problema com zero valores. O aluno protestou: "Descontar tudo só porque me enganei nos cálculos?". Ao que o professor respondeu "Acha lógico que a água possa sair a $-10^{\circ} \mathrm{C}$ ?". $\mathrm{O}$ aluno após pensar um pouco responde "Pois claro que não pode: $\mathrm{a}-10^{\circ} \mathrm{C}$ estava congelada e não podia sair dos tubos"!!!

3. ${ }^{\circ}$ Exemplo: Numa aula de laboratórios de Química-Física $\left(3{ }^{\circ}\right.$ ano de licenciatura em Eng. Química) o aluno tem de fazer uma determinação de um índice de refracção de uma mistura orgânica num refractómetro de Abbé. 0 apareIho, no entanto, não dá o valor do índice directamente. Têm depois de se consultar tabelas que convertem a leitura no aparelho no valor do índice de refracção (para além de outras correcções posteriores devidas a vários factores). Acontece que um nónio ${ }^{5}$ existente no aparelho, permite fazer a leitura com uma casa decimal a mais relativamente aos valores das tabelas. Já não me lembro exactamente dos valores em causa mas vamos imaginar que o número lido era 26,885 e na tabela vinha $n=1,55034$ para o valor de 26,88 e $n=1,55042$ para o valor de 26,89 .

Ao passar pela bancada eu disse ao aluno "Pronto, então o índice de refracção não corrigido é de 1,55038 . Vamos agora corrigi-lo".

O aluno olhou para mim com grande desconfiança e pergunta "A professora tem a certeza? Como é que sabe sem fazer a conta?". "Mas eu fiz a conta: fiz mentalmente. É um caso tão simples". Ele pega na pasta, abre a pasta, tira uma máquina de calcular, último modelo, liga a máquina, digita furiosamente uma série de algarismos e diz triunfalmente: "Vê professora, enganou-se; afinal dá 1,55015!". Pacientemente, lá Ihe expliquei que o valor interpolado não podia ficar fora do intervalo $[1,55034$. 1,55042]. Continuou desconfiado, digitou novamente uma série de caracteres e diz-me: "Não professora, não me enganei a digitar os algarismos está tudo certo e dá mesmo 1,55015. Pedi-lhe entâo para me explicar o que tinha feito. Tinha ajustado uma recta aos pontos $(26,88,1,55034)$ e $(26,89,1,55042$, e depois calculou o " $y$ " para um " $x=26,885 "$. Expliquei-Ihe então que com um tão grande número de casas decimais era natural que a máquina fizesse aproximaçōes que fossem responsáveis pelo erro. Foi estudar o manual da máquina, onde estava explicado que havia na máquina já instalado um programa para fazer aquele tipo de interpolaçōes. Meia hora (ou mais) depois, o aluno obtinha finalmente na máquina 0 resultado que eu the tinha anunciado e que eu obtive em fracçōes de segundo (e grande parte das pessoas da minha geração, mesmo sem qualquer curso superior, obteria).

E para não maçar mais o leitor, paro aqui com os exemplos.

Não vou aqui pretender que estes casos sejam representativos, sobretudo os dois últimos que incidem apenas sobre um aluno. Mas podia contar centenas deles talvez com um cariz menos anedótico mas todos com um mesmo denominador comum: um divórcio muito grande, nos alunos actuais, entre a capacidade de pensar, de raciocinar, e a capacidade de calcular. De calcular com calculadora, claro! Cálculo mental, nem pensar! Isso era na idade média!

Por este comentário não se pense que eu sou contra o uso dos últimos avanços tecnológicos na escola. Bem pelo contrário! E quem me conhece bem, sabe-o. Tal como não sou contra o uso de meios de transporte motorizados. Acho mesmo que, em muitos aspectos, representaram uma libertação para a nossa espécie. Agora far-me-ia muita confusâo se os humanos perdessem a sua capacidade de andar pelo facto de existirem automóveis. Imaginem o que seria (pelo menos os deficientes motores devem perceber muito bem a situação) se todos nós tivéssemos de usar um veículo motorizado para ir do quarto para a casa de banho, da cozinha para a sala de jantar, do gabinete para o laboratório, 
da sala de aula para o refeitório da escola, etc...

Para além deste aspecto imediato do cálculo mental, penso que ele pode também ser uma das melhores ferramentas para exercitar a mente, sobretudo em individuos muito jovens. Pode, assim, ser uma peça fundamental para desenvolver a capacidade de raciocínio. E essa é fundamental mesmo que se tenha na mochila a calculadora mais artilhada do mundo.

É certo que o raciocínio meramente intuitivo nos pode enganar e por isso deve ser complementado (mas nunca substituido) sempre que possivel com cálculos que confirmam ou não as conclusões qualitativas. Agora, não é menos verdade que a ditadura dos cálculos sem o acompanhamento do raciocínio é, porventura, ainda mais perigosa.

A este respeito, é muito interessante um artigo recente publicado no J. Chem. Education $^{6}$ sobre uma investigação dos factores que influenciam o desempenho dos estudantes na disciplina de Química-Física. Não vou aqui resumir a metodologia usada nem todas as conclusões atingidas pelo autor mas apenas respigar uma ou duas frases do artigo que me tocaram particularmente e vêm dar suporte mais sólido à percepção que tenho do sentido em que deve caminhar o ensino pelo menos dos alunos destinados ao Ensino Superior: "...Breaking down the math diagnostic by the types of questions asked, we found that the item most significantly correlated with course grade was the ability to solve word problems..." . Os outros "items" do teste de matemática compreendiam cálculo básico (integração/diferenciação), álgebra (resolução de sistemas de equa- çōes, ou seja, cálculo matricial) e cálculo avançado (equações diferenciais, expansão em série de Taylor). Isto é, mesmo numa disciplina em que os professores lamentam que a formação matemática dos alunos não seja mais avançada e que os alunos temem por "ter" muita matemática, o teste feito evidencia que mais importante do que a aquisição prévia de ferramentas matemáticas, é a capacidade de raciocínio, a capacidade para compreender.

A capacidade de intervenção de cada um de nós, em particular, nos curricula escolares é, porventura muito limitada sobretudo nos curricula dos primeiros ano de ensino. Agora o que podemos é, enquanto professores que lidam com vários escalões etários de alunos, contribuir para a mudança de mentalidades e de atitudes relativamente ao saber. Nomeadamente que a abordagem quantitativa de um problema não substitui a abordagem qualitativa; complementa-a. Que a máquina de calcular deve ser usada como um instrumento de ajuda e não como uma droga de que se depende de modo doentio. Que a capacidade de raciocínio, fundamental para resolver problemas novos, se exercita diariamente e quanto mais cedo se começar meIhor. Dei aqui o exemplo, porque vinha a talhe de foice, do papel do cálculo mental nesse exercício mas há muitos outros exercícios com papel idêntico. Os nossos especialistas em Pedagogia devem conhecê-los bem. Por favor, numa altura em que se apela tanto aos professores que ensinem os alunos a aprender. eu imploro: ensinem-nos, a nós professores, a ensinar! Aos professores de todos os graus de ensino. Ensinem-nos a pôr os nossos alunos a raciocinar e não a debitar a receitas e a depender doentiamente da máquina de calcular.

Referências

[1] Esta é uma das injustiças da História: os responsáveis por esta designação foram os soldados do Senhor de La Palice (e não ele) que em seu louvor compuseram uma canção onde se encontrava uma afirmação de uma evidência simplória (verdade de La Palice): "Un quart d'heure avant sa mort, II était encore en vie".

[2] Que, parece, mudou de designação. Nisso o nosso ensino é pródigo. Para que não haja confusões: Ensino Primário é aqui usado como sinónimo dos quatro primeiros anos de ensino obrigatório (a antiga $4 .^{a}$ classe) e Ensino Secundário como sinónimo dos 8 anos seguintes.

[3] Objectivo assumido pelo responsável ministerial pela elaboração dos programas de Matemática para o Ensino Secundário (e de cujo nome me esqueci...) durante as Jornadas Pedagógicas que decorreram no Instituto Superior Técnico em Lisboa no ano de 1999.

[4] Numa liga de substituição, átomos do metal base são substituídos nas suas posições da rede cristalina por átomos de outro ou outros elementos. Uma liga intersticial é formada por ocupação de interstícios da rede cristalina por átomos de outro ou outros elementos. Quando o elemento extra está presente em pequena percentagem a ocupação de interstícios ou a substituição de átomos da rede dá-se sem modificação do volume molar do metal base.

[5] Por incrivel que pareça, são pouquíssimos os alunos que chegam a um curso de Engenharia tendo já ouvido falar de um e nầ encontrei ainda nenhum que soubesse justificar o seu funcionamento! Que diabo, é das poucas invenções portuguesas!

[6] G. Nicoll, J. Francisco, J. Chem. Educ., 78 (2001) 99
"In my hunt for the secret of life, I started my research in histology. Unsatisfied by the information that cellular morphology could give me about life, I turned to physiology. Finding physiology too complex, I took up pharmacology. Still finding the situation too complicated, I turned to bacteriology. But bacteria were even too complex, so, I descended to the molecular level, studying chemistry and physical chemistry. After twenty years' work, I was led to conclude that to understand life we have to descend to the electronic level and to the world of wave mechanics. But electrons are just electrons and have no life at all. Evidently on the way I lost life; it had run out between my fingers."

Albert Szent-Györgyi (personal Reminiscences). 